\title{
Seroprevalence, spatial analysis and risk factors of infection with Neospora caninum in cattle in Brazil's northern Pantanal wetland
}

\author{
Soroprevalência, análise espacial e fatores de risco da infecção por Neospora caninum em bovinos \\ no Pantanal norte do Brasil \\ Ana Carolina Schmidt ${ }^{1,2}$; Thábata dos Anjos Pacheco ${ }^{1,3}$; Janice Elena Ioris Barddal ${ }^{1,4}$; \\ Anderson Castro Soares de Oliveira ${ }^{1}$; Daniel Moura de Aguiar ${ }^{1}$; Rísia Lopes Negreiros ${ }^{2}$; \\ Richard de Campos Pacheco ${ }^{1 *}$
}

\begin{abstract}
${ }^{1}$ Programa de Pós-graduação em Ciências Veterinárias - PPGVET, Faculdade de Medicina Veterinária - FAVET, Universidade Federal de Mato Grosso - UFMT, Cuiabá, MT, Brasil

${ }^{2}$ Instituto de Defesa Agropecuária do Estado de Mato Grosso - INDEA-MT, Cuiabá, MT, Brasil

${ }^{3}$ Instituto Federal de Rondônia - IFRO, Cacoal, RO, Brasil

${ }^{4}$ Ministério da Agricultura, Pecuária e Abastecimento - MAPA, Cuiabá, MT, Brasil
\end{abstract}

Received May 3, 2018

Accepted July 10, 2018

\begin{abstract}
Neosporosis is caused by an obligate intracellular protozoan, Neospora caninum. It is considered one of the most widespread and frequent causes of abortion in cattle worldwide. To evaluate the prevalence of anti- $N$. caninum antibodies and associated risk factors, serum samples were collected from 2,452 bovines at 262 farms in the northern Pantanal, state of Mato Grosso, Brazil. Each farmer was asked to fill out a questionnaire for subsequent epidemiological data analysis. Anti- $N$. caninum antibodies were detected by means of the indirect immunofluorescent assay (IFA), using a cut-off dilution of 1:100. The overall anti- $N$. caninum antibodies prevalence was $25.44 \%$ (Confidence Interval - CI 95\%; $20.10 \% ; 30.78 \%$ ), and the anti- $N$. caninum antibodies prevalence per herd was $76.72 \%$ (CI 95\%; 71.60\%; 81.84\%). The presence of dogs, occurrence of abortion in cows, and sale of cattle for breeding were statistically associated with seropositivity in herds, while the risk of females being seropositive for $N$. caninum was higher in animals $\leq 6$-years-old and in the presence of dogs. A spatial analysis indicated that the relative risk of the disease is spatially constant and that the farms with the highest prevalence of anti- $N$. caninum antibodies are located south of the region under study.
\end{abstract}

Keywords: Neosporosis, antibodies, epidemiology, indirect immunofluorescent assay.

\section{Resumo}

Neosporose é causada por um protozoário intracelular obrigatório, Neospora caninum. É considerada uma das causas mais comuns e frequentes de aborto em bovinos em todo o mundo. Para avaliar a prevalência de anticorpos anti- $N$. caninum e fatores de risco associados, amostras de soro foram coletadas de 2.452 bovinos em 262 fazendas no Pantanal norte, estado de Mato Grosso, Brasil. Cada fazendeiro preencheu um questionário para posterior análise dos dados epidemiológicos. Anticorpos anti- $N$. caninum foram detectados por meio da reação de imunofluorescência indireta (RIFI), utilizando um ponto de corte de 1:100. A prevalência total de anticorpos anti- $N$. caninum foi de 25,44\% (Intervalo de Confiança - IC 95\%; 20,10\%; 30,78\%) e a prevalência por rebanho foi de 76,72\% (IC 95\%; 71,60\%; 81,84\%). A presença de cáes, a ocorrência de abortamento em vacas e a venda de bovinos para reprodução estiveram estatisticamente associadas à soropositividade em rebanhos, enquanto, o risco de fêmeas serem soropositivas para $N$. caninum foi maior em animais com idade $\leq 6$ anos e na presença de cáes. A análise espacial indicou que o risco relativo da doença é espacialmente constante e que as fazendas com maior prevalência de anticorpos anti- $N$. caninum estáo localizados ao sul da regiáo em estudo.

Palavras-chave: Neosporose, anticorpos, epidemiologia, imunofluorescência indireta.

\footnotetext{
*Corresponding author: Richard de Campos Pacheco. Programa de Pósgraduaçẫo em Ciências Veterinárias - PPGVET, Faculdade de Medicina Veterinária - FAVET, Universidade Federal de Mato Grosso - UFMT, Av. Fernando Corrêa da Costa, 2367, Boa Esperança, CEP 78060-900, Cuiabá, MT, Brasil. e-mail: richard@ufmt.br
} 


\section{Introduction}

Neosporosis is one of the most widespread and frequent causes of bovine abortion and stillbirths around the world (MCALLISTER, 2016), leading to huge economic losses (REICHEL et al., 2013). This disease is caused by an obligate intracellular protozoan, Neospora caninum, which belongs to the phylum Apicomplexa, class Sporozoa, order Eucoccidiorida and the family Sarcocystidae (DUBEY et al., 2002).

Transmission to bovines occurs through the ingestion of sporulated oocysts released into the environment by the definitive host, particularly domestic dogs (Canis familiaris) (DONAHOE et al., 2015). Infection may also occur, and herd infection levels may be maintained through transplacental infection by infected cows during gestation (exogenous transmission), or through reactivation of existing bradyzoites in the body of the infected cow (endogenous transmission). In both cases, the tachyzoites cross the placental barrier during gestation (TREES \& WILLIAMS, 2005).

The Pantanal is the largest continuous floodplain in the world. It is located in central South America, in the Upper Paraguay River basin, encompassing parts of Brazil, Paraguay and Bolivia. In Brazil, the Pantanal covers a region of $-140,000 \mathrm{~km}^{2}, 35 \%$ of which is located in the state of Mato Grosso and corresponds to $7 \%$ of the state. The main economic activity in the Pantanal is grass-fed cattle farming, mainly in the stages of breeding and finishing, with -2.09 million head distributed on 7,772 ranches, representing $7.32 \%$ of the state's cattle herd. Mato Grosso has the largest cattle herd in the country, with -28.5 million animals distributed on 102,162 ranches (ABREU et al., 2010; INDEA, 2014).

Cattle farming is one the state's most important economic activities. Mato Grosso beef exports generated 1.2 billion USD in 2014. This represents $18.71 \%$ of all Brazilian beef exports (ACRIMAT, 2015). In 2015, Mato Grosso produced 1.17 million tons of beef, and was Brazil's second largest exporter, exporting a total of 298 thousand tons (ACRIMAT, 2016). In Brazil, annual economic losses in dairy farming due to neosporosis have been estimated at 51.3 million USD (varying between 35.8 and 111.3 million dollars). $N$. caninum-related losses in Brazil's beef industry have been estimated at 101 million dollars (varying from 63.6 to 111.7 million), according to Reichel et al. (2013).

This study focused on an investigation into the presence of anti- $N$. caninum antibodies in bovines and in the identification of associated factors that affect anti- $N$. caninum antibodies prevalence in cattle herds in the northern Pantanal wetland of Mato Grosso state, Brazil.

\section{Materials and Methods}

\section{Study area}

Farms in the municipalities of Cáceres, Poconé, Barão de Melgaço, Santo Antônio de Leverger and Nossa Senhora do Livramento located in the northern Pantanal, within the Mato Grosso state, were chosen for this study (Figure 1).

\section{Serum collection and epidemiological information}

Serum samples were collected primarily for another study on the epidemiology of brucellosis in bovines in the state of Mato Grosso, which was conducted from September to December 2014 (BARDDAL et al., 2016). Initially, the state was divided into regions, taking into consideration the different production systems, management practices, types of operation, average herd sizes, animal commercialization system, and the operational capacity of the animal health protection service. Within each of these regions, a predetermined number of farms with reproductive activity (primary sampling units) were randomly chosen. This process was based on farm records maintained by the Mato Grosso Institute for Agricultural Defense (INDEA-MT). Within each selected farm, a predetermined number of cows aged over 24 months were drawn at random (secondary sampling units). In the northern Pantanal ecoregion 3,024 animals were sampling at 262 farms (BARDDAL et al., 2016).

The proportion of samples in the five municipalities located in the northern Pantanal was verified in the database generated by Barddal et al. (2016), and the farms sampled for the present study were proportionally drawn using the Microsoft Excell 2010, according to the sample calculation described below. Sampling of animals at each farm remained the same as the study conducted by Barddal et al. (2016). Concomitant to sampling, each farmer was asked to fill out a questionnaire for subsequent epidemiological data analysis.

\section{Sampling}

Sampling was done in two stages. The first involved selecting a preestablished number of random farms (primary sampling units) to estimate disease foci, which resulted in the sampling of 262 farms (Table 1). After this, a preestablished number of cows aged over 24 months (secondary sampling units) were selected.

The random draw was carried out at the farm by the Official Veterinarian responsible for sampling, taking into consideration the total number of females aged over 24 months as described below. The sample size was calculated using the algebraic expression (SCHEAFFER et al., 2011):

$$
\mathrm{N}_{0}=\left[\mathrm{Np}(1-\mathrm{p}) /(\mathrm{N}-1)\left(\mathrm{d} / \mathrm{Z}_{\alpha / 2}\right)^{2}+\mathrm{p}(1-\mathrm{p})\right] \cdot \text { deff }
$$

where $\mathrm{n}$ is size of the population, $p$ is the prevalence to be estimated, $d$ is the margin of error or maximum error of the estimation, $z_{-}(\alpha / 2)$ is a tabulated value of the normal distribution and deff is the effect of the sample design.

This is used to estimate proportions, considering 50\% as absolute prevalence of anti- $N$. caninum antibodies, $6 \%$ as an estimate of maximum error, $95 \%$ as confidence interval (CI) and 1.5 as experimental design effect.

The sampling plan for the secondary units was aimed at estimating the minimum number of animals to be examined on each farm to determine whether it was a focus of bovine neosporosis. To this end, the concept of aggregated sensitivity and specificity was used (DOHOO et al., 2003). The sample size needed to estimate herd 


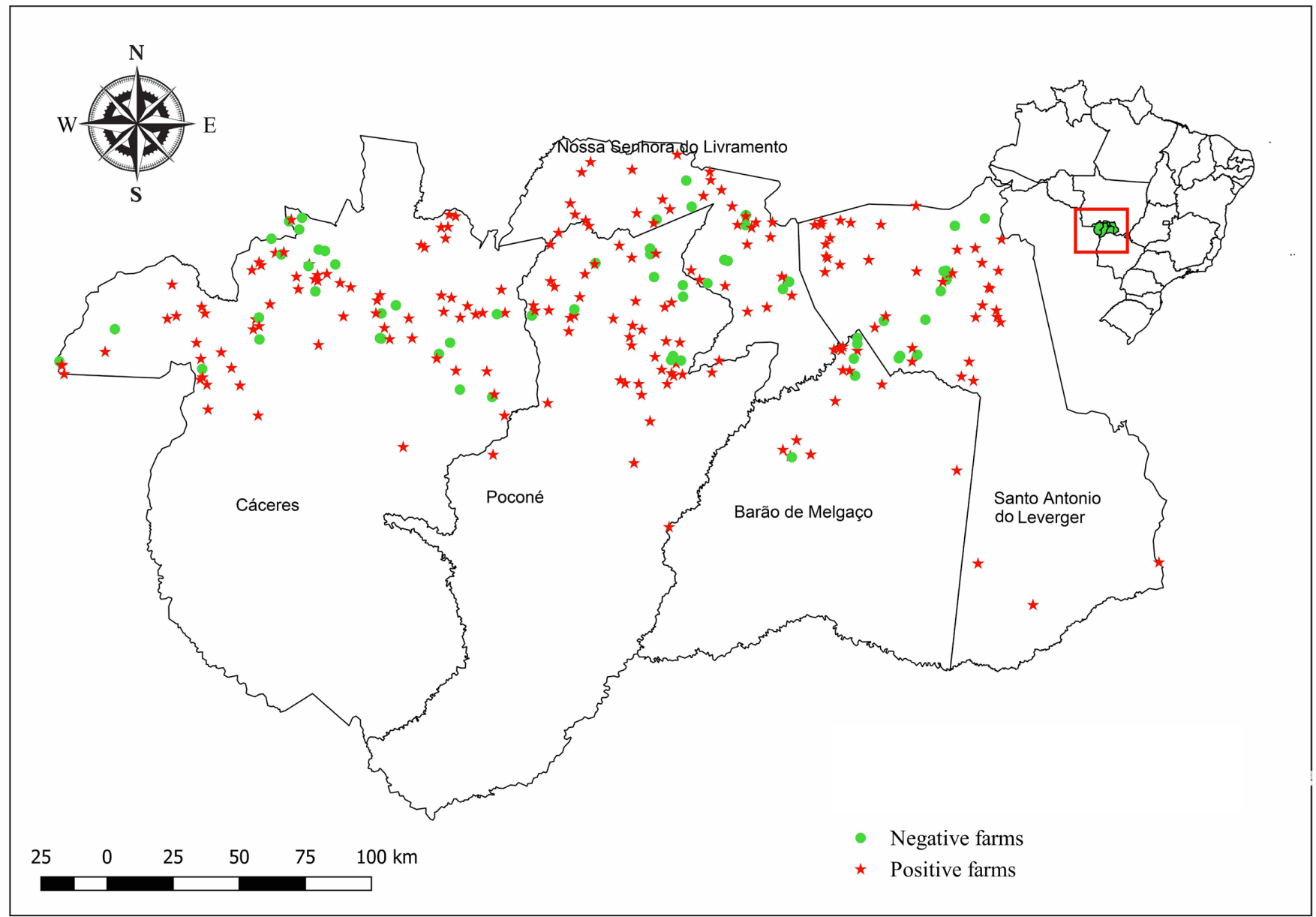

Figure 1. Distribution of farms sampled for the detection of anti-Neospora caninum antibodies in the municipalities of Cáceres, Poconé, Barão de Melgaço, Nossa Senhora do Livramento and Santo Antônio do Leverger located in the northern Pantanal of Mato Grosso state, Brazil, between September and December 2014.

Table 1. Number of cattle farms and cows sampled in the northern Pantanal of Mato Grosso state, Brazil, between September and December 2014. Columns left to right: (1) Municipalities of the northern Pantanal of Mato Grosso state, Brazil; (2) Total number of farms in each municipality; (3) Number of farms sampled in the current survey; (4) Number of > 24-month-old cows sampled in the current survey.

\begin{tabular}{lccc}
\hline \multicolumn{1}{c}{ Municipality } & $\begin{array}{c}\text { No. of } \\
\text { farms }\end{array}$ & $\begin{array}{c}\text { No. of sampled } \\
\text { farms }\end{array}$ & $\begin{array}{c}\text { No. of } \\
\text { sampled cows }\end{array}$ \\
\hline Barão de Melgaço & 583 & 21 & 203 \\
Cáceres & 2848 & 94 & 1003 \\
Nossa Senhora do & 1215 & 43 & 352 \\
Livramento & & & \\
Poconé & 1530 & 52 & 423 \\
$\begin{array}{l}\text { Santo Antônio do } \\
\text { Leverger }\end{array}$ & 1602 & 52 & 471 \\
Total & & & \\
\hline
\end{tabular}

sensitivity and specificity values of $\geq 90 \%$ was chosen using the Herdacc version 3 software program. Considering the secondary sampling unit, sample size was preestablished according to the number of cows older than 24 months on each farm. In farms with up to 99 female bovines, 10 animals were sampled; 15 animals were sampled in farms with 100 or more female animals older than 24 months. All the animals were sampled on farms that had fewer than ten cows. Thus, 2,452 serum samples were collected (Table 1).

\section{Indirect immunofluorescence assay}

Serum samples were tested by means of indirect immunofluorescence assay (IFA) to detect the presence of $N$. caninum antibodies, as described by Dubey et al. (1988). N. caninum tachyzoites (isolate $\mathrm{NC}-1)$ maintained in Vero cell cultures were used as antigens, as well as anti-bovine IgG conjugate (Sigma, St Louis, MO, USA), at a 1:1200 dilution. Test sensitivity and specificity were estimated at $98 \%$ and $99 \%$, as described by Packham et al. (1998).

Serum samples were considered positive when most of the fixed tachyzoites $(>50 \%)$ showed total peripheral fluorescence at a 1:100 dilution. Reactions with partial or apical fluorescence were considered negative (BJORKMAN \& UGGLA, 1999). Each slide contained serum previously shown to be non-reactive (negative control) and serum known to be reactive (positive control). This positive control serum was previously shown to 
react with $N$. caninum at an endpoint titer of 1:12,800. All the positive samples were confirmed by two evaluators and retested at dilutions of $1: 100,1: 400,1: 6,400$ and $1: 12,800$.

\section{Prevalence, statistical and spatial analysis}

Anti- $N$. caninum antibody prevalence on the farms and among the animals were expressed in the form of confidence intervals (THRUSFIELD, 2007), and the anti-N. caninum antibody prevalence of the animals were calculated using weighted values (DOHOO et al., 2003). The following expression was used to determine the weighted value of each animal: (total number of $>24$-month-old females on the farm) / (total of $>24$-month-old females sampled on the farm) X (total of > 24-month-old females in the region) / (total of $>24$-month-old females sampled in the region).

The anti- $N$. caninum antibody prevalence on each farm was analyzed considering that a farm would be positive if at least one animal tested positive. A multiple logistic regression model was created in several steps, as follows. Step I - For the continuous variables, a linearity test was performed using Graphs for Log Odds. When the visual evaluation indicated a nonlinear trend, the continuous variable was categorized. The optimization methodology of the software package CatPredi $\mathrm{R}$ was used (BARRIO et al., 2017); Step II - for the categorical variables, a chi-square or exact Fisher test was performed on the results and the various predictor variables, and all the variables with a value of $\mathrm{p}<0.20$ were incorporated into the model; Step III - the selected variables were tested for collinearity including multicollinearity analysis, according to Vatcheva et al. (2016), to ensure a mean variance inflation factor $(\mathrm{VIF})<10$, before applying them in the models; Step IV - the model was constructed by inserting all the variables selected in the previous steps. The less significant variables (according to the Wald test) were then removed and the logistic regression analysis was repeated. This process was repeated, and the adjusted model compared to the previous one by means of the likelihood ratio test to check for confounding factors. Whenever there was a change of more than $30 \%$ in the parameter estimates, the removed variable was considered a confounding factor and again included in the model.

The variables used to construct the herd model were: exploitation type (beef, dairy or dual-purpose); type of rearing (confined or atpasture); use of artificial insemination (yes or no); predominant breed (European beef or dairy, zebu or hybrid); presence of a dogs on the farm (yes or no); presence of sheep or goats on the farm (yes or no); presence of equines on the farm (yes or no); wildlife on the farm (yes or no); presence of free-roaming wild deer on the farm (yes or no); presence of freely-roaming capybaras on the farm (yes or no); whether any cow aborted in the last 12 months (yes or no); how was the aborted fetus or placenta disposed of (incinerated/buried, or other form of disposal); were cows purchased as breeders (yes or no); source from which they were purchased (auction/exhibition, cattle dealer or other farm); were cows or bulls sold for breeding (yes or no); to whom (auction/exhibition, cattle breeder or another farm); was slaughtering performed on the farm (yes or no); how often (monthly or semestrally); location of slaughter of adult males and females at the end of their reproductive life (on the farm itself; at an establishment not subject to veterinary inspection; at an establishment subject to veterinary inspection; no slaughter); are any paddocks rented at any time of the year (yes or no); are there any wetland areas to which cattle have access on the farm (yes or no); are there separate paddocks for post-calving females (yes or no); is veterinary assistance sought (yes or no); are feeders or water springs shared with other farms (yes or no); does the farm have a drovers' rest area (yes or no) and number of $>24$ month-old cows on the farm ( $\leq 78$ females or $\geq 79$ females).

The animals were analyzed following the same steps as those used to analyze the farms. However, complex analysis, according to Korn \& Graubard (1999), was applied to the tests in order to correct the effect of the selection of animals, for which weighted values were used, as described above.

The model was built using the following variables: age in years, classified as less than or equal to 6 years and greater than 6 years, the presence of wild animals and that of dogs. The split at the age of 6 years was defined in the optimization methodology of the software package CatPredi R (BARRIO et al., 2017) and the average found was 6,167 years.

Based on Kernel estimation, a risk map can be created using spatial data, expressed as: $R(s)=\lambda 1(s) / \lambda O(s)$; where $\lambda 1(\mathrm{~s})$ is the Kernel positive density estimate and $\lambda 0(\mathrm{~s})$ is the Kernel negative density estimate. The basic assumption is that risk is spatially constant and is expressed as: $R O(s)=n 1 / n 0$; where $\mathrm{n} 1$ is the total number of positive locations and $n 0$ is the total number of negative locations. The significance of the test was determined by means of the Monte Carlo test (KELSALL \& DIGGLE, 1995). The marked correlation function was used to verify the existence of a spatial pattern, expressed as:

$$
\widehat{\rho_{\mathrm{f}}}(\mathrm{d})=\frac{1}{\mathrm{n}(\mathrm{h})-\mu^{2}} \sum_{\mathrm{i}=1}^{\mathrm{n}} \sum_{\mathrm{j}=1}^{\mathrm{m}} \mathrm{f}\left(\mathrm{m}_{\mathrm{I}}, \mathrm{m}_{\mathrm{j}}\right)
$$

where $n(h)$ is the number of pairs of points with distance $h ; m_{l}, m_{J}$ are the marks associated with the points $i$ and $j ; f\left(m_{p}, m_{f}\right)=m_{I} \times m_{J}$ if the mark is quantitative; $f\left(m_{P}, m_{J}\right)=\mathrm{I}\left(m_{I}=m_{J}\right)$ if the mark is qualitative.

To verify the hypothesis of randomness an envelope is obtained from Monte Carlo simulations. (OLINDA \& SCALON, 2010).

Statistical analysis was performed using the $\mathrm{R}$ statistical software package (R DEVELOPMENT CORE TEAM, 2015), and the Spatstat package (BADDELEY \& TURNER, 2005). For the spatial analysis, the Kernel intensity estimator was used to analyze the behavior of patterns of points and to estimate the pointwise intensity of the process throughout the entire state.

This study was approved by the Animal Research Ethics Committee of the Federal University of Mato Grosso, under reference no. 23108.112018/2015-45.

\section{Results}

Here, in the studied area of the Brazilian northern Pantanal wetland, the anti- $N$. caninum antibody prevalence of the total population was $25.44 \%$ (CI 95\%; $20.10 \% ; 30.78 \%$ ), with titers ranging from 100 and 12,800. The frequency distribution of endpoint titers was as follows: 168 (29.80\%) serum samples showed 
titers of $100 ; 210(37.30 \%)$ showed titers of $400 ; 132(23.40 \%)$ had titers of 1,$600 ; 35(6.3 \%)$ had titers of 6,400; and showed $18(3.20 \%)$ titers of 12,800 for $N$. caninum. Moreover, $N$. caninum antibodies were detected in at least one animal on 201 of the 262 analyzed farms (Figure 1), resulting in a seroprevalence of 76.72\% (CI 95\%; 71.60\%; 81.84\%) among herds.

In the multivariate analysis, after the model was applied, three variables were found to be significantly associated with the prevalence of anti- $N$. caninum antibodies on the farms: the presence of dog, a history of abortion in the preceding 12 months, and the sale of cattle for breeding. Two confounding variables were also found: the presence of capybaras and that of equines (Table 2). Table 3 describes the relationship between the presence of anti-N. caninum antibodies and the variables of the logistic model. Two variables were significantly associated with bovines testing positive for $N$. caninum (the presence of dogs and the age of the animal), as indicated in Table 4. Table 5 described the relationship between the presence of anti- $N$. caninum antibodies and the variables of the logistic model of the 2,452 animals sampled in the northern Pantanal of Mato Grosso state, Brazil.

Figure 2 shows the marked correlation function for the spatial distribution of positive and negative farms. Note that no relationship was found between the location of a farm and the serological findings, since all the values obtained fell within the confidence interval, indicating that the spatial occurrence of positive farms was random.

The spatial distribution of anti- $N$. caninum antibody prevalence on the farms, based on kernel estimation, indicated that seroprevalence varied from 0.10 to 0.35 , with the highest intra-herd seroprevalence in the southern region (Figure 3).

The spatial distribution of the farms and their seroprevalence showed a marked correlation (Figure 4), and the prevalence

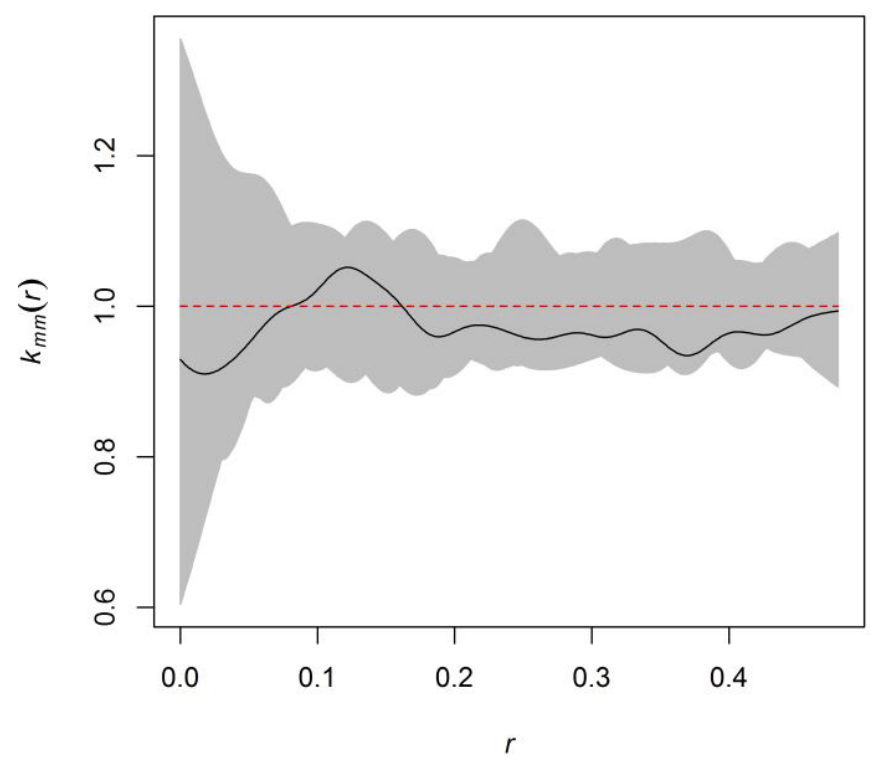

Figure 2. Marked spatial distribution correlation function for farms positive and negative for Neospora caninum in the northern Pantanal of Mato Grosso state, Brazil, between September and December 2014. Where $K_{M M}(r)$ is the marked correlation function and $r$ is the distance between farms given in radius.
Table 2. Results of the logistic regression model for risk factors associated with anti-Neospora caninum antibody prevalence on the 262 farms sampled in the northern Pantanal of Mato Grosso state, Brazil, between September and December 2014.

\begin{tabular}{lccccc}
\hline \multicolumn{1}{c}{$\begin{array}{c}\text { Associated } \\
\text { variable }\end{array}$} & Estimate & p-value & $\begin{array}{c}\text { Odds } \\
\text { Ratio }\end{array}$ & \multicolumn{2}{c}{ CI** $^{* *} \%$} \\
\hline $\begin{array}{l}\text { Presence of a dog } \\
\text { on the farm? }\end{array}$ & 0.60 & 0.03 & 1.83 & 1.04 & 3.26 \\
$\begin{array}{l}\text { Any cow or } \\
\text { buffalo aborted } \\
\text { during the last } 12\end{array}$ & 0.75 & 0.04 & 2.13 & 1.04 & 4.75 \\
months? & & & & & \\
$\begin{array}{l}\text { Are cows or bulls } \\
\text { sold for breeding? }\end{array}$ & 0.83 & 0.02 & 2.30 & 1.14 & 4.99 \\
$\begin{array}{l}\text { Presence of } \\
\text { freely-roaming } \\
\text { capybaras on the } \\
\text { farm?* }\end{array}$ & 0.53 & 0.14 & 1.70 & 0.85 & 3.55 \\
$\begin{array}{l}\text { Presence of } \\
\text { equines on the } \\
\text { farm?* }\end{array}$ & 0.28 & 0.34 & 1.33 & 0.73 & 2.41 \\
\hline *Confounding variables; ${ }^{* *}$ Confidence Interval. & & & \\
\hline
\end{tabular}

Table 3. Relationship between the presence of anti- Neospora caninum antibodies and the variables of the logistic model, on the 262 farms sampled in the northern Pantanal of Mato Grosso state, Brazil, between September and December 2014.

\begin{tabular}{lcc}
\hline \multicolumn{1}{c}{ Associated variable } & Positive & Negative \\
\hline Presence of a dog on the farm? & 172 & 42 \\
Yes & 29 & 19 \\
No & & \\
Any cow or buffalo aborted during the last & & \\
12 months? & 67 & 10 \\
$\quad$ Yes & 134 & 51 \\
No & & \\
Are cows or bulls sold for breeding? & 69 & 11 \\
Yes & 132 & 69 \\
No & & \\
Presence of freely-roaming capybaras on the & & \\
farm? & 73 & 73 \\
$\quad$ Yes & 128 & 48 \\
No & & \\
Presence of equines on the farm? & 171 & 43 \\
$\quad$ Yes & 30 & 18 \\
$\quad$ No
\end{tabular}

Table 4. Results of the logistical regression model for risk factors associated with the prevalence of anti-Neospora caninum antibodies in individual bovines in the northern Pantanal of Mato Grosso state, Brazil, between September and December 2014.

\begin{tabular}{lccccc}
\hline $\begin{array}{c}\text { Associated } \\
\text { variable }\end{array}$ & Estimate & p-value & $\begin{array}{c}\text { Odds } \\
\text { Ratio }\end{array}$ & \multicolumn{2}{c}{ CI** 95\% $^{*}$} \\
\hline $\begin{array}{l}\text { Presence of } \\
\text { a dog on the }\end{array}$ & 0.21 & $<0.0001$ & 1.25 & 1.14 & 1.34 \\
farm & & & & & \\
Animal age* & 0.06 & 0.02 & 1.07 & 1.01 & 1.13 \\
\hline
\end{tabular}

*Age in years, considering 24-month-old cows classified as $\leq 6$-year-old and $>6$-year-old cows; ${ }^{* *}$ Confidence Interval. 
depends on the location of the farm. Points that lay outside the confidence interval suggest that seroprevalence on a farm is related to its location, given that the values of points are lower than 1 , indicating regular patterns.

Table 5. Results of the relationship between the presence of anti-Neospora caninum antibodies and the variables of the logistic model, pertaining to the 2,452 animals sampled in the northern Pantanal of Mato Grosso state, Brazil, between September and December 2014.

\begin{tabular}{ccc}
\hline Associated variable & $\begin{array}{c}\text { Positive } \\
\text { Real/Adjusted }\end{array}$ & $\begin{array}{c}\text { Negative } \\
\text { Real/Adjusted }\end{array}$ \\
\hline Animal age & & \\
$\leq 6$ & $417 / 435^{*}$ & $1357 / 1253^{*}$ \\
$>6$ & $146 / 189^{*}$ & $532 / 575^{*}$ \\
Presence of a dog on the farm. & & \\
Yes & $477 / 576^{*}$ & $1520 / 1614^{*}$ \\
No & $86 / 48^{*}$ & $369 / 215^{*}$ \\
\hline
\end{tabular}

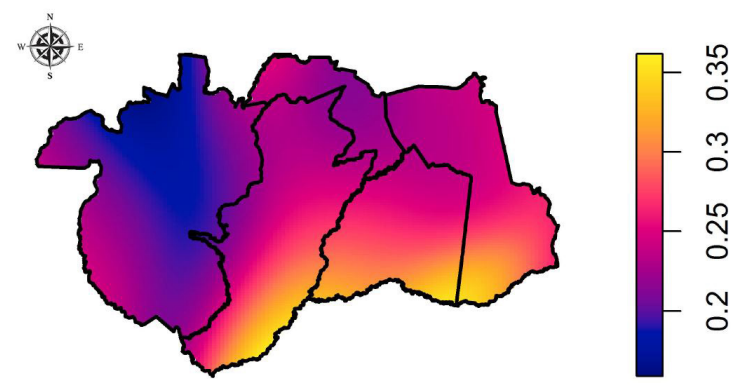

Figure 3. Spatial distribution of intra-herd prevalence of anti-Neospora caninum antibodies determined by means of the Kernel Estimator in the northern Pantanal of Mato Grosso state, Brazil, between September and December 2014.

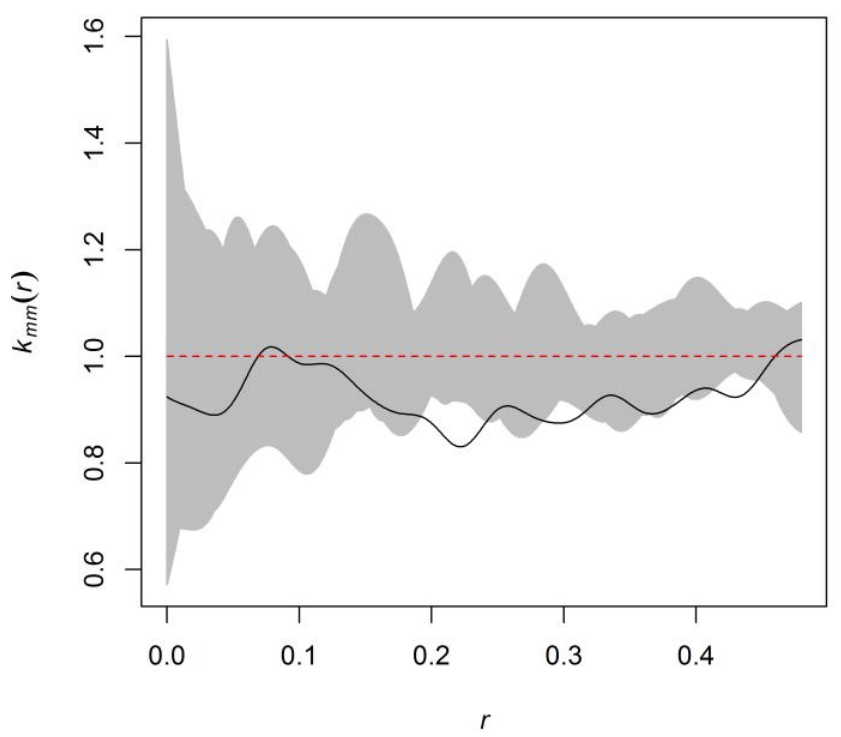

Figure 4. Marked spatial distribution function of the farms and their anti-Neospora caninum antibody prevalence in the northern Pantanal of Mato Grosso state, Brazil, between September and December 2014. Where $K_{M M}(r)$ is the marked correlation function and $r$ is the distance between farms given in radius.
Moreover, a process of repulsion was identified between seroprevalence, and farms with high values were intercalated with farms with low seroprevalence. Farms with high prevalence have, as neighbors, farms with low prevalence, indicating this process of repulsion.

\section{Discussion}

Taken together, $76.72 \%$ of the sampled farms had at least one animal that tested positive for $N$. caninum and the high anti- $N$. caninum antibody prevalence among the animals (25.44\%) indicate that neosporosis is widespread in the northern Pantanal of Mato Grosso state, midwestern Brazil.

Comparisons with other studies of anti- $N$. caninum antibody prevalence should be made cautiously, considering the use of different serological techniques, age at slaughter, sample size and animal population type, according to Dubey et al. (2007). In Brazil, prevalence of anti- $N$. caninum antibodies against bovine neosporosis reportedly vary from $6.80 \%$ to $89.70 \%$, (GENNARI, 2004; AGUIAR et al., 2006; OSHIRO et al., 2007; MINERVINO et al., 2008; CARDOSO et al., 2012; BRUHN et al., 2013). In the southwestern region of the state of Mato Grosso, a 53.50\% prevalence of anti- $N$. caninum antibodies was identified in dairy cattle on 24 evaluated farms, and at least one seropositive animal per farm was found (BENETTI et al., 2009). Moreover, prevalence of $37.56 \%$ and $2.45 \%$ of animals seropositive for anti- $N$. caninum antibodies were observed on five farms in the northern region and in the municipality of Nossa Senhora do Livramento, respectively, in the State of Mato Grosso (JUSTO et al., 2013; RODRIGUES et al., 2016).

The current study demonstrated that $32 \%$ of the positive sera had titers equal to or higher than 1,600, demonstrating that the history of abortion in bovines on farms in the northern Pantanal could be associated with infection by $N$. caninum, given that the analysis of factors associated with the history of abortion indicates that the probability of an animal being seropositive increases by 2.13-fold. According to McAllister (2016), cows can show high levels of antibodies specific to the pathogen after aborting. The author considers that $N$. caninum titers of 1,600 are associated with abortion and titers equal to or higher than 6,400 are very probably associated with abortion. Seropositive cows are at higher risk of abortion than seronegative ones because this risk increases with the increase in individual levels of anti- $N$. caninum antibodies (CORBELLINI et al., 2002). The possibility of abortion among seropositive cows is two to seven times more likely to occur than among seronegative animals (DUBEY \& SCHARES, 2011), and this risk is 7.4-fold higher among congenitally affected heifers (THURMOND \& HIETALA, 1997). However, an additional study should be performed to analyze the aborted fetus to confirm the infection and lesions by $N$. caninum.

Andreotti et al. (2010) demonstrated in a study conducted in beef cattle herds from Brazil's southern Pantanal wetland of the Mato Grosso Sul state, that the presence of $N$. caninum seropositive heifers has caused a significant impact on reproduction, with a reduction of $21.88 \%$ in the extraction rate of the herd. Furthermore, there was a negative impact on the herd benefit rate with the presence 
of cows seropositive for neosporosis, since the output rate for heifers seropositive and seronegative to neosporosis was $28.24 \%$ and $50.12 \%$, respectively, showing a $44 \%$ reduction in the output rate of heifers seropositive to $N$. caninum in the Pantanal ecoregion of Mato Grosso do Sul state, Brazil (BARROS et al., 2011). So, further studies are necessary to evaluate the possibly impact on reproduction and the economic losses caused by neosporosis in the studied area, since the main economic activity in the northern Pantanal of Mato Grosso state is grass-fed cattle farming.

It was observed that presence of dogs was found to increase the probability of detection of anti- $N$. caninum antibodies in bovines and farms by 1.25 and 1.83-fold, respectively. The presence of a dog on a farm as a potential risk factor for bovine neosporosis, because dogs are the definitive host for $N$. caninum, and are responsible for the introduction of the disease in cattle herds (MCALLISTER et al., 1998; GOODSWEN et al., 2013). Furthermore, dogs allowed to roam freely on cattle ranches showed a higher rate of seropositivity for $N$. caninum than confined dogs, because they are more likely to eat fetuses or placenta from cows infected with $N$. caninum (SCHARES et al., 2003, 2004; ROBBE et al., 2016).

The association of neosporosis with the sale of males and females for breeding (2.30-fold probability) may have to do with the disposal of animals due to reproductive problems, since the main economic activity in the northern Pantanal of Mato Grosso state is pasture-based cattle farming, especially in the phases of growth and fattening (ABREU et al., 2010). This information is important for the adoption of measures to control neosporosis in the region given that, in herds where the disease is endemic, seropositive females are often responsible for perpetuating the disease for generations because they can produce congenitally infected calves (BJORKMAN et al., 1996). The endogenous transmission rate varies from 41 to $86 \%$ (MCALLISTER, 2016).

The exploratory spatial analysis carried out in this study indicated that the distribution of farms with respect to the spatial relative risk of the disease is constant in space. No conglomeration, or clusters that indicate that high prevalence farms have neighbors with high prevalence and farms with low prevalence have neighbors with low prevalence, was observed in the region under study, and the occurrence of at least one animal positive for $N$. caninum was found to be independent of its geographic location in the northern Pantanal of Mato Grosso state. However, Boas et al. (2015) reported the birth of weak calves and the presence of $N$. caninum on farms located near one another in northern Brazil, indicating the occurrence of aggregation of the disease.

Studies have suggested that there is a difference in the risk of $N$. caninum infection among different geographical regions, production systems and environmental temperatures (RINALDI et al., 2005; GHALMI et al., 2012), and that there is a prevalence of anti-N. caninum antibodies in herds that live in regions with higher temperatures (SCHARES et al., 2003; RINALDI et al., 2005). In this study, the absence of conglomeration is likely attributable to the fact that the farms have similar cattle production management systems. Moreover, farms located in the same geographic area are exposed to the same weather conditions.

However, with respect to anti- $N$. caninum antibody prevalence among animals on the farms, it was also found that the farms with the highest prevalence were located in the southern part of the region under study. This may have to do with the individual characteristics of these farms, which directly influence the number of seropositive bovines. Dubey et al. (2007) stated that risk factors associated with higher animal seropositivity rates were an increase in the number of dogs on the farm, the presence of $N$. caninum intermediate hosts, the adoption of supplementary feeding practices, an increase in bovine herd density, and the practice of replacing heifers with those bred on the farm. Silva et al. (2008) found that farms with higher anti- $N$. caninum antibody prevalence had animals whose nutritional status was classified as poor, whereas seroprevalence were lower on farms where the animals' nutritional status was normal.

Few studies have investigated possible effects on the spatial distribution of infection by $N$. caninum in bovines, although a significant positive correlation has been identified with the population density of dogs on ranches and with the vegetation profile (SCHARES et al., 2003; RINALDI et al., 2005). Therefore, further analyses are needed to investigate the effects of such covariates in the Brazil's northern Pantanal ecoregion.

\section{Conclusions}

This is the first study that has identified anti- $N$. caninum antibody prevalence in bovines and farms located in the Brazil's northern Pantanal wetland. Bovine neosporosis, which is widely distributed throughout this region, is associated with a history of abortion, the presence of dogs, and the sale of breeding cows. Spatial analysis demonstrated that the relative risk of the disease is constant in space, and that the farms with the highest anti- $N$. caninum antibody prevalence are located in the southern part of the region under study.

\section{Acknowledgements}

The authors gratefully acknowledge INDEA/MT for its technical support during the field work and for providing serum samples, as well as CAPES (Federal Agency for the Support and Improvement of Higher Education) for its financial support of this work, and CNPq (National Council for Scientific and Technological Development) for the awarding a research productivity grant to D. M. Aguiar and R.C. Pacheco.

\section{References}

Abreu UGP, Mcmanus C, Santos SA. Cattle ranching, conservation and transhumance in Brazilian Pantanal. Pastoralism 2010; 1(1): 99-114.

Aguiar DM, Cavalcante GT, Rodrigues AA, Labruna MB, Camargo LM, Camargo EP, et al. Prevalence of anti-Neospora caninum antibodies in cattle and dogs from Western Amazon, Brazil, in association with some possible risk factors. Vet Parasitol 2006; 142(1-2): 71-77. http://dx.doi. org/10.1016/j.vetpar.2006.06.014. PMid:16857319.

Andreotti R, Barros JC, Pereira AR, Oshiro LM, Cunha RC, Figueiredo LF No. Association between seropositivity for Neospora caninum and reproductive performance of beef heifers in the Pantanal of Mato Grosso 
do Sul, Brazil. Rev Bras Parasitol Vet 2010; 19(2): 119-123. http://dx.doi. org/10.1590/S1984-29612010000200010. PMid:20624350.

Associação dos Criadores de Mato Grosso - ACRIMAT. Informativo mensal da Associaçâo dos Criadores de Mato Grosso [online]. Cuiabá: ACRIMAT; 2015. (vol. 52). [cited 2018 Apr 30]. Available from: https://acrimat. org.br/portal/publicacoes/informativo-mensal/

Associação dos Criadores de Mato Grosso - ACRIMAT. Informativo mensal da Associação dos Criadores de Mato Grosso [online]. Cuiabá: ACRIMAT; 2016. (vol. 67). [cited 2018 Apr 30]. Available from: https://acrimat. org.br/portal/publicacoes/informativo-mensal/page/2/

Baddeley A, Turner R. Spatstat: an R package for analyzing spatial point patterns. J Stat Softw 2005; 12(6): 1-42. http://dx.doi.org/10.18637/ jss.v012.i06.

Barddal JEI, Quixabeira-Santos JC, Lopes IF, Ferreira JS No, Ferreira F, Amaku M, et al. Effect of vaccination in lowering the prevalence of bovine brucellosis in the state of Mato Grosso, Brazil. Semina: Ciênc Agrár 2016;37(5 Suppl 2): 3479-3492. http://dx.doi.org/10.5433/16790359.2016v37n5Supl2p3479.

Barrio I, Arostegui I, Rodríguez-Álvarez M, Quintana JM. A new approach to categorising continuous variables in prediction models: Proposal and validation. Stat Methods Med Res 2017; 26(6): 2586-2602. http://dx.doi. org/10.1177/0962280215601873. PMid:26384514.

Barros JC, Figueiredo LF No, Fagundes MBB, Andreotti R. Economic assessment of neosporosis in beef cattle system performance with different technological levels. Semina: Ciênc Agrár 2011;32(4 Suppl 2): 1943-1954. http://dx.doi.org/10.5433/1679-0359.2011v32n4Sup1p1943.

Benetti AH, Schein FB, Santos TR, Toniollo GH, Costa AJ, Mineo $\mathrm{JR}$, et al. Pesquisa de anticorpos anti-Neospora caninum em bovinos leiteiros, cães e trabalhadores rurais da região Sudoeste do Estado de Mato Grosso. Rev Bras Parasitol Vet 2009;18(Suppl 1): 29-33. http:// dx.doi.org/10.4322/rbpv.018e1005. PMid:20040187.

Bjorkman C, Johansson O, Stenlund S, Holmdahl OJ, Uggla A. Neospora species infection in a herd of dairy cattle. J Am Vet Med Assoc 1996; 208(9): 1441-1444. PMid:8635995.

Björkman C, Uggla A. Serological diagnosis of Neospora caninum infection. Int J Parasitol 1999; 29(10): 1497-1507. http://dx.doi.org/10.1016/ S0020-7519(99)00115-0. PMid:10608435.

Boas RV, Pacheco TA, Melo AL, Oliveira AC, Aguiar DM, Pacheco RC. Infection by Neospora caninum in dairy cattle belonging to family farmers in the northern region of Brazil. Rev Bras Parasitol Vet 2015; 24(2): 204208. http://dx.doi.org/10.1590/S1984-29612015035. PMid:26154960.

Bruhn FRP, Daher DO, Lopes E, Barbieri JM, Rocha CMBM, Guimarães AM. Factors associated with seroprevalence of Neospora caninum in dairy cattle in southeastern Brazil. Trop Anim Health Prod 2013; 45(5): 1093 1098. http://dx.doi.org/10.1007/s11250-012-0330-y. PMid:23212838.

Cardoso JMS, Amaku M, Araújo AJUS, Gennari SM. A longitudinal study of Neospora caninum infection on three dairy farms in Brazil. Vet Parasitol 2012; 187(3-4): 553-557. http://dx.doi.org/10.1016/j. vetpar.2012.01.019. PMid:22309800.

Corbellini LG, Driemeier D, Cruz CFE, Gondim LFP, Wald V. Neosporosis as a cause of abortion in dairy cattle in Rio Grande do Sul, southern Brazil. Vet Parasitol 2002; 103(3): 195-202. http://dx.doi.org/10.1016/ S0304-4017(01)00600-8. PMid:11750112.

Dohoo IR, Martin SW, Stryhn H. Veterinary epidemiologic research. Charlottetown: AVC Inc.; 2003.
Donahoe SL, Lindsay SA, Krockenberger M, Phalen D, Slapeta J. A review of neosporosis and pathologic findings of Neospora caninum infection in wildlife. Int J Parasitol Parasites Wildl 2015; 4(2): 216-238. http://dx.doi. org/10.1016/j.ijppaw.2015.04.002. PMid:25973393.

Dubey JP, Barr BC, Barta JR, Bjerkas I, Bjorkman C, Blagburn BL, et al. Redescription of Neospora caninum and its differentiation from related coccidia. Int J Parasitol2002; 32(8): 929-946. http://dx.doi.org/10.1016/ S0020-7519(02)00094-2. PMid:12076623.

Dubey JP, Carpenter JL, Speer CA, Topper MJ, Uggla A. Newly recognized fatal protozoan disease of dogs. J Am Vet Med Assoc 1988; 192(9): 12691285. PMid:3391851.

Dubey JP, Schares G, Ortega-Mora LM. Epidemiology and control of neosporosis and Neospora caninum. Clin Microbiol Rev 2007; 20(2): 323-367. http://dx.doi.org/10.1128/CMR.00031-06. PMid:17428888.

Dubey JP, Schares G. Neosporosis in animals: the last five years. Vet Parasitol 2011; 180(1-2): 90-108. http://dx.doi.org/10.1016/j.vetpar.2011.05.031. PMid:21704458.

Gennari SM. Neospora caninum no Brasil: situação atual da pesquisa. Rev Bras Parasitol Vet 2004; 13(Suppl 1): 23-28.

Ghalmi F, China B, Ghalmi A, Hammitouche D, Losson B. Study of the risk factors associated with Neospora caninum seroprevalence in Algerian cattle populations. Res Vet Sci 2012; 93(2): 655-661. http:// dx.doi.org/10.1016/j.rvsc.2011.12.015. PMid:22244708.

Goodswen SJ, Kennedy PJ, Ellis JT. A review of the infection, genetics, and evolution of Neospora caninum: from the past to the present. Infect Genet Evol2013; 13: 133-150. http://dx.doi.org/10.1016/j.meegid.2012.08.012. PMid:22985682.

Indea MT. Banco de dados do sistema informatizado de animais. Cuiabá: Instituto de Defesa Agropecuária do Estado de Mato Grosso; 2014.

Justo RV, Manfio JB, Galhardo JA, Garcia JL, Campos AK. Seroepidemiological inquiry on bovine neosporosis in northern Mato Grosso state, Brazil. Semina: Ciênc Agrár 2013;34(6 Suppl 2): 3897-3902. http://dx.doi. org/10.5433/1679-0359.2013v34n6Supl2p3889.

Kelsall JE, Diggle PJ. Non-parametric estimation of spatial variation in relative risk. Stat Med 1995; 14(21-22): 2335-2342. http://dx.doi. org/10.1002/sim.4780142106. PMid:8711273.

Korn EL, Graubard BI. Analysis of health surveys. New York: John Wiley \& Sons; 1999. (Wiley Series in Probability and Statistics). http://dx.doi. org/10.1002/9781118032619.

McAllister MM, Dubey JP, Lindsay DS, Jolley WR, Wills RA, McGuire AM. Dogs are definitive hosts of Neospora caninum. Int J Parasitol 1998 28(9): 1473-1478. http://dx.doi.org/10.1016/S0020-7519(98)00138-6. PMid:9770635.

McAllister MM. Diagnosis and control of bovine neosporosis. Vet Clin North Am Food Anim Pract 2016; 32(2): 443-463. http://dx.doi. org/10.1016/j.cvfa.2016.01.012. PMid:27161392.

Minervino AHH, Ragozo AMA, Monteiro RM, Ortolani EL, Gennari SM. Prevalence of Neospora caninum antibodies in cattle from Santarém, Pará, Brazil. Res Vet Sci 2008; 84(2): 254-256. http://dx.doi.org/10.1016/j. rvsc.2007.05.003. PMid:17619028.

Olinda RA, Scalon JD. Métodos de Monte Carlo para análise de processos pontuais marcados. Rev Bras Biol 2010; 28(1): 39-56.

Oshiro LM, Matos MF, Oliveira JM, Monteiro LA, Andreotti R. Prevalence of anti-Neospora caninum antibodies in cattle from the state of Mato 
Grosso do Sul, Brazil. Rev Bras Parasitol Vet 2007; 16(3): 133-138. http:// dx.doi.org/10.1590/S1984-29612007000300004. PMid:18078599.

Packham AE, Sverlow KW, Conrad PA, Loomis EF, Rowe JD, Anderson ML, et al. A modified agglutination test for Neospora caninum: development, optimization, and comparison to the indirect fluorescent-antibody test and enzyme-linked immunosorbent assay. Clin Diagn Lab Immunol 1998; 5(4): 467-473. PMid:9665950.

R Development Core Team. R: a language and environment for statistical computing [online]. Vienna: The R Foundation for Statistical Computing; 2015 [cited 2018 May 3]. Available from: http://www.R-project.org/

Reichel MP, Ayanegui-Alcérreca MA, Gondim LF, Ellis JT. What is the global economic impact of Neospora caninum in cattle - The billiondollar question. Int J Parasitol 2013; 43(2): 133-142. http://dx.doi. org/10.1016/j.ijpara.2012.10.022. PMid:23246675.

Rinaldi L, Fusco G, Musella V, Veneziano V, Guarino A, Taddei $\mathrm{R}$, et al. Neospora caninum in pastured cattle: determination of climatic, environmental, farm management and individual animal risk factors using remote sensing and geographical information systems. Vet Parasitol 2005; 128(3-4): 219-230. http://dx.doi.org/10.1016/j.vetpar.2004.12.011. PMid: 15740859 .

Robbe D, Passarelli A, Gloria A, Di Cesare A, Capelli G, Iorio R, et al. Neospora caninum seropositivity and reproductive risk factors in dogs. Exp Parasitol 2016; 164: 31-35. http://dx.doi.org/10.1016/j. exppara.2016.02.003. PMid:26873272.

Rodrigues RS, Igarashi LS, Muraro LS, Gomes AHB, Aguiar DM, Pacheco TA, et al. The occurrence of anti-Neospora caninum in bovine female animals and bovine fetuses in Nossa Senhora do Livramento
County, Mato Grosso. Semina: Ciênc Agrár 2016; 37(6): 4161-4166. http://dx.doi.org/10.5433/1679-0359.2016v37n6p4161.

Schares G, Bärwald A, Staubach C, Ziller M, Klöss D, Schröder R, et al. Potential risk factors for bovine Neospora caninum infection in Germany are not under the control of the farmers. Parasitology 2004; 129(3): 301309. http://dx.doi.org/10.1017/S0031182004005700. PMid:15471005.

Schares G, Bärwald A, Staubach C, Ziller M, Klöss D, Wurm R, et al. Regional distribution of bovine Neospora caninum infection in the German state of Rhineland-Palatinate modelled by Logistic regression. Int J Parasitol 2003; 33(14): 1631-1640. http://dx.doi.org/10.1016/ S0020-7519(03)00266-2. PMid:14636679.

Scheaffer RL, Mendenhall W, Ott L, Gerow KG. Elementary survey sampling. Boston: PWS-Kent; 2011.

Silva MIS, Almeida MAO, Mota RA, Pinheiro-Junior JW, Rabelo SSA. Fatores de riscos associados à infecção por Neospora caninum em matrizes bovinas leiteiras em Pernambuco. Cienc Anim Bras 2008; 9(2): 455-461.

Thrusfield MV. Veterinary epidemiology. Oxford: Blackwell Science; 2007.

Thurmond MC, Hietala SK. Effect of congenitally acquired Neospora caninum infection on risk of abortion and subsequent abortions in dairy cattle. Am J Vet Res 1997; 58(12): 1381-1385. PMid:9401685.

Trees AJ, Williams DJ. Endogenous and exogenous transplacental infection in Neospora caninum and Toxoplasma gondii. Trends Parasitol 2005; 21(12): 558-561. http://dx.doi.org/10.1016/j.pt.2005.09.005. PMid:16223599.

Vatcheva KP, Lee M, McCormick JB, Rahbar MH. Multicollinearity in regression analyses conducted in epidemiologic studies. Epidemiol 2016; 6(2): 227. http://dx.doi.org/10.4172/2161-1165.1000227. PMid:27274911. 